\title{
Heat extraction from hypersaline mine water at the Dawdon mine water treatment site
}

M.T. Bailey The Coal Authority, UK

A.M.L. Moorhouse The Coal Authority, UK

I.A. Watson The Coal Authority, UK

\begin{abstract}
Mine closure needs to take consideration of the potential wider environmental and economic value of the mine infrastructure and surface environs. An area of growing interest in the exploitation of abandoned mine sites as an economic resource is the heat recoverable from mine waters or as a sink for heat from cooling applications. Mine site restorations and redevelopments can benefit from potentially vast quantities of 'green' heat energy, facilitated by considered mine abandonment (ensuring open shafts remain secure and monitoring recovery of water levels, for example). Pumping of waters, or engineered gravity outflows from mine workings, are often required post-closure to prevent uncontrolled discharges as water levels rebound; in these cases the water source is readily accessible. Alternatively, viable heating schemes may actively abstract mine water, with a specific objective of recovering heat, before discharging it at surface or reinjecting it into the mine.

Mine waters are, however, often characterised as poor quality, with high concentrations of pyrite oxidation products and dissolved solids being typical. While temperatures of mine waters can be favourable for highly efficient heat-pump coupled space heating applications, concerns over damage to heat exchangers due to poor water quality may limit their application. Research has been conducted to assess the impacts of hypersaline and ferruginous mine water on a heat pump system, which could provide large amounts of lowcarbon heating at mine site redevelopments.

A pilot-scale heat pump has been installed within the Coal Authority's Dawdon mine-water treatment facility in the northeast of England and has been in operation for more than two years. Flows of $1 \mathrm{~L} / \mathrm{s}$ of untreated coal mine water containing $>70 \mathrm{mg} / \mathrm{L}$ iron, and water treated to remove iron to $<1 \mathrm{mg} / \mathrm{L}$ for environmental purposes, have been passed through heat exchangers coupled to an 'off the shelf' domestic heat pump. Space heating and hot water were provided to an office complex that is part of the mine-water treatment facility. Results indicate that water treated to substantially reduce iron concentrations can still cause blockage of heat exchangers with iron oxyhydroxide precipitates. However, in systems isolated from the atmosphere, poor quality untreated water did not cause clogging of heat exchangers in the trial period and thus is not liable to be a significant obstacle for application of commercially available heat exchangers in mine-water-sourced heating schemes.
\end{abstract}

Presented in this paper are the details of the heat pump setup, water quality data and geochemical modelling to demonstrate the importance of a sealed system for the use of raw mine water. On the basis of practical experience, some advice will be provided for mine closure planning in order to facilitate minewater heating systems in site redevelopments. 
1

\section{Introduction}

\subsection{Background}

Widespread closure of UK coal mines, which formed a nationalised industry, occurred in the latter part of the twentieth century for economic and political reasons. Today, only a few operational mines remain on a vastly undermined urban landscape.

The Coal Authority, established in 1994 following privatisation of the industry, is now statutorily responsible for coal reserves in the UK, in addition to the many tens of thousands of coal mines that were abandoned before the adoption of the Coal Industry Act [1994]. Upon its formation by Parliament, the Authority was specifically tasked with managing mine-water emissions, as set out by Lord Strathclyde, and has developed a successful programme of remediation (Parker, 2003). More than 60 treatment schemes are in operation throughout the UK, treating coal mine waters to remove iron before discharge to the environment. Additionally, the Coal Authority actively manages mine waters within specific hydraulically interconnected 'blocks' of mine workings (Figure 1). This is required, for example, where rebounding water levels following mine closure are at risk of causing pollution in the future (see, e.g., Wyatt et al., 2013).

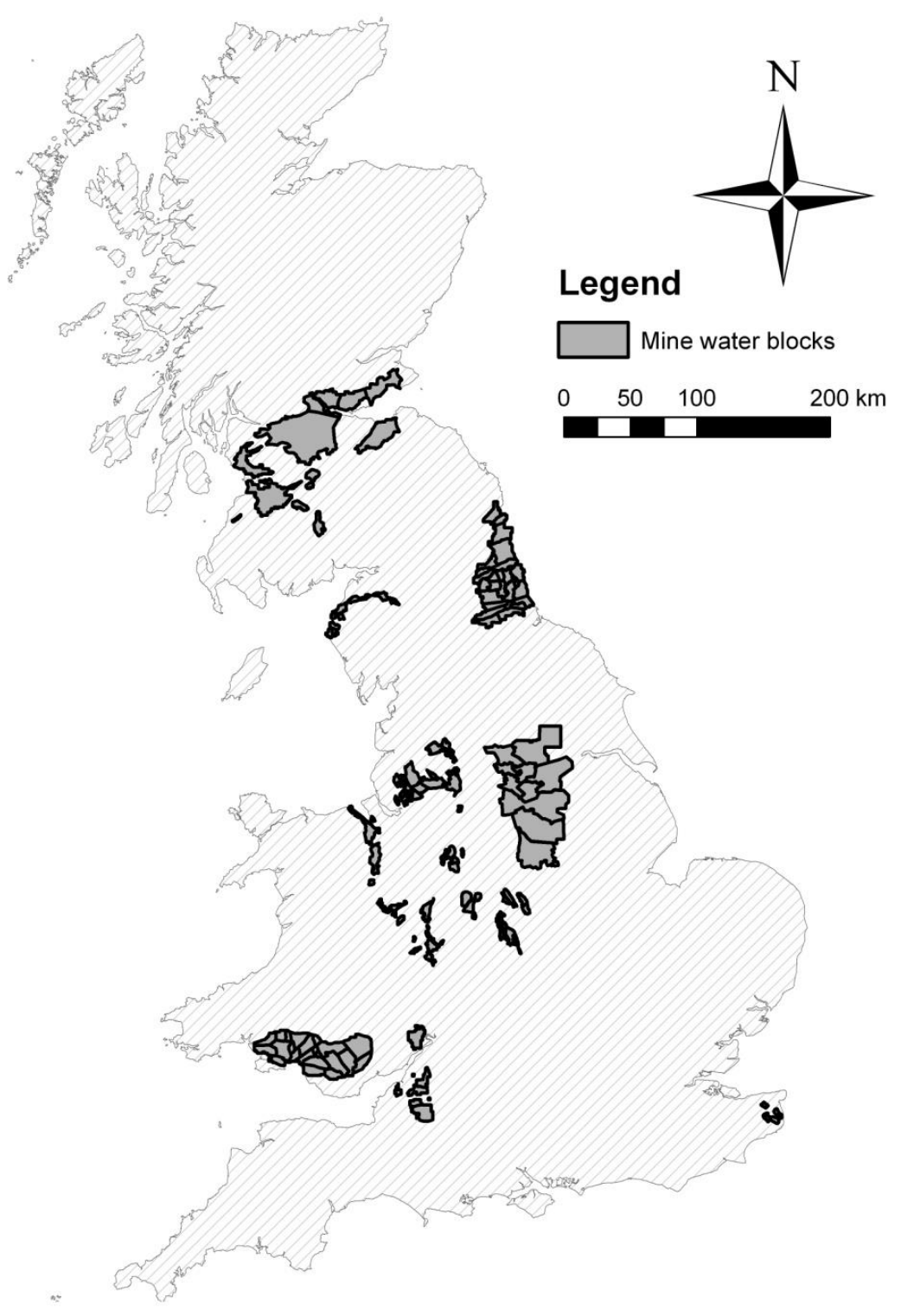

Figure 1 Mine water blocks managed by the Coal Authority 


\subsection{Mine water for space heating and cooling}

Considerable interest is emerging in the application of mine water as a source for heat-pump-coupled space heating or cooling applications at UK sites. Deep mine waters throughout the UK often have a perennially consistent temperature throughout extensive mine networks and thus can provide a useful source of or sink for heat. Abstracted deep mine waters are fed through the heating or cooling system before being returned to the mine workings in an 'open loop' configuration. The prospect of these schemes is particularly attractive for developments situated on abandoned mine sites (as is commonplace in the UK due to the amount of former mine sites earmarked for preferential 'brownfield' redevelopment). Despite this, there are very few examples of mine-water-sourced heating or cooling schemes in the published literature. Existing examples include systems in Scotland (Banks et al., 2009), Canada (Jessop et al., 1995); Germany, Norway and the USA (Hall et al., 2011) and the Netherlands (Roijen, 2011; Banks et al., 2003). It is suspected that the apparent lack of implementation is a result of both lack of confidence in the method (not many exemplar schemes can be cited) and the availability of cheaper alternatives (such as groundsourced systems), particularly relating to installation costs, which may deter developers.

Vast void spaces left by mining activities provide a considerable advantage for open-loop mine-watersourced heating or cooling systems for the following reasons (after Wieber and Pohl, 2008; Banks et al., 2003; Watzlaf et al., 2002):

- Mined voids provide excellent heat exchange with surrounding bedrock.

- Significant depths can be readily accessed from open/unfilled mine entries.

- Substantial volumes of water are accessible, and abstractions can be highly productive.

- High-flow discharges often already exist, or mine-water pumping takes place for operational or environmental reasons.

Mine-water-sourced heat pumps can consequently represent an economical and effective way of accessing a substantial geothermal resource.

Mine abandonment can be integrated with installing mine-water-coupled heating or cooling systems; leaving surface infrastructure in place, such as access ways and power supplies, upon the closure of deep mines can aid in the development of heat pump schemes. More importantly, unfilled shafts can facilitate extensive monitoring of mine-water recovery and temperature but also can be used for thermal response testing and, where suitable, ongoing mine-water abstraction. Remote shafts left unfilled also represent a significant asset for the monitoring of water levels and temperatures after development of the scheme, in order to ensure resource sustainability. By carefully considering site conditions upon abandonment, minewater-sourced heating/cooling schemes can be developed in a more cost-effective manner, addressing one of the principal concerns raised by developers and potentially acting as a catalyst for redevelopment.

Mine waters are, however, typically poor quality, with low pH (acidic) and supersaturated with dissolved solids. Concerns regarding corrosion of heat pump components, combined with the accretion and blockage of heat exchangers with precipitates, can often result in proposals falling out of favour (Watzlaf and Ackman, 2006). This issue is considered further later in this paper.

\subsection{Examples of schemes utilising mine water in Scotland}

Banks et al. (2009) provides a review of the operational performance of the only two UK-based full-scale open-loop mine-water-sourced heat pumps known to the authors at the time of writing, situated at Shettleston in Glasgow and at Lumphinnans, Fife. Both these schemes extract heat from untreated mine water. A quick summary of some relevant points in the paper are provided.

Following a pilot mine-water-sourced heat pump trial in 1992 at Mossend, Lanarkshire, full-scale systems were finally developed at Shettleston in 1999 and at Lumphinnans in 2000. Water is abstracted from the workings using submersible pumps, screened for suspended debris and passed through the evaporator 
heat exchanger in the heat pump unit, before being reinjected below the water table by a separate well. Statistics for the systems are provided in Table 1.

Table 1 Statistics for two Scottish mine-water-based ground-sourced heat systems, after Banks et al. (2009)

\begin{tabular}{ccc}
\hline & Shettleston & Lumphinnans \\
\hline Abstraction well depth $(\mathrm{m})$ & 100 & 172.5 \\
Recharge well depth $(\mathrm{m})$ & $50-60$ & $50-60$ \\
Horizontal well separation $(\mathrm{m})$ & 20 & 100 \\
Heat pump rating $\left(\mathrm{kW}_{\mathrm{th}}\right)$ & 65 & 65 \\
Influent mine water temperature $\left({ }^{\circ} \mathrm{C}\right)$ & 12 & 14.5 \\
$\mathrm{pH}$ & - & 6.2 \\
Iron concentration $(\mathrm{mg} / \mathrm{L})$ & - & 58 \\
Conductivity $(\mathrm{mS} / \mathrm{cm})$ & - & 2.56 \\
Eh & - & Reducing (-ve) \\
\hline
\end{tabular}

Both systems provide water for space heating to apartment blocks at $\sim 55^{\circ} \mathrm{C}$ and hot water (further heated by electric immersion heaters). The Shettleston scheme was a new build of 16 units; Lumphinnans was a refurbishment of 18 units. Since installation, with the exception of vandalism to the recharge well, the systems have operated with only routine maintenance for in-line filter renewal (every three months) and pump replacement.

\section{$1.4 \quad$ Heat pump technology}

Temperatures of mine-water sources throughout the UK are generally modest yet stable $\left(10-20^{\circ} \mathrm{C}\right.$ may be typical). While it is feasible to extract heat from these sources, by circulating fluid through buried pipes or a heat exchanger, the relatively low temperature heat is of little use for practical applications, such as heating water for conventional radiators (typically operating at $>50^{\circ} \mathrm{C}$ ), for space heating or for hot water. Thermal energy will simply not flow from a lower temperature media to one of a higher temperature. While 'passive' cooling may be achieved using a sufficiently large and efficient networks of pipes within a building, through which mine water could flow, the cooling effect is limited (Banks, 2008). Fortunately, technology exists that allows heat to be 'pumped' from one media to another, against the thermal gradient, thus enhancing the heating or cooling available by passive methods.

Conventional heat pumps utilise the Rankine cycle, a condensation-evaporation cycle of a fluid with a suitably low boiling point. A compressor forces the fluid to condense, releasing heat energy as it changes state. The condensed fluid flows through an expansion valve before collecting heat energy in the evaporator (a heat exchanger interfaced with the source). This vapour then passes back into the compressor to complete the cycle. In effect, low-grade heat energy from the source is 'pumped' upgradient in order to provide thermal energy at a useable temperature, consuming a proportionately modest amount of electricity.

An ideal opportunity existed for the Coal Authority to develop and test a mine-water-sourced heat pump application, given the vast amounts of water that are managed as part of its environmental duty. As the abstraction costs are already accounted for, the cost of implementation for a whole system (either pilot or full-scale, given the mine water volumes managed) is considerably reduced. A pilot-scale, demonstration unit was installed at a mine-water abstraction and treatment facility in the northeast of England, at the site of the former Dawdon Colliery. 


\subsection{Dawdon mine-water treatment facility}

Rising mine waters following widespread coal mine closures in the coastal mining area of County Durham, UK, were identified as at risk of flowing into the regionally important overlying Permian Magnesian limestone aquifer. Due to the hypersaline and sulphate-rich nature of the mine water, considerable deterioration of water quality of the aquifer would result from relatively small flows. Consequently, a longterm abstraction strategy was considered necessary to control mine-water levels at a lesser head than water levels within the aquifer, and active mine-water treatment facilities were installed first at Horden (2004, temporary plant) and Dawdon (2008). In 2011, the active Horden facility was replaced with a greener passive system. At Dawdon, a high-density sludge (HDS) active treatment system is employed, housed within an industrial steel-framed and clad building in order to comply with local planning requirements. Submersible pumps positioned $-69.6 \mathrm{mAOD}$ (well head level: $33.3 \mathrm{mAOD}$ ) within the Dawdon Colliery Theresa Shaft provide mine water to the HDS plant and control the shaft water level at 47 mAOD (optimum). Six inset roadways connected to the Theresa Shaft are situated between $-250 \mathrm{~m}$ and the base of the shaft at $-500 \mathrm{mAOD}$. The pumping station delivers up to $150 \mathrm{~L} / \mathrm{s}$ via a rising main to the treatment plant $850 \mathrm{~m}$ away and at $72.75 \mathrm{mAOD}$. Influent mine water is treated with the addition of lime and a polymer flocculent, in order to reduce in-stream iron concentrations before final discharge to the North Sea. The iron is recovered as a high-density sludge that is taken from the plant for industrial applications.

\subsection{Mine water quality}

Discharge water quality is carefully controlled by the active treatment process, and consequently remains relatively stable, excepting occasional times when the plant fails. During failure, suspended ochre particles can be carried through the system and into the discharge tank. Table 2 provides an indicative snapshot of treated and untreated mine-water quality and temperature during normal operation, taken from on-site measurements. Note that suspended solids data are not presented: the standard method exposes the sample to atmospheric oxygen, encouraging precipitation of dissolved iron and any other substances that may be present within the mine-water sample. These conditions are unrepresentative of the conditions in the sealed heat exchanger and ancillary pipe work, and thus data are unreliable.

Table 2 Some mine-water parameters for the Dawdon mine-water treatment plant

\begin{tabular}{ccccccc}
\hline & \multicolumn{3}{c}{ Influent (Raw) } & \multicolumn{3}{c}{ Effluent (Treated) } \\
\hline & $22 / 02 / 2012$ & $07 / 03 / 2012$ & $24 / 10 / 2012$ & $22 / 02 / 2012$ & $07 / 03 / 2012$ & $24 / 10 / 2012$ \\
Fe (mg/l, total) & 74 & 71 & 72 & 0.51 & 0.25 & 0.87 \\
$\mathrm{pH}$ & 6.9 & 6.8 & 6.7 & 7.2 & 7.3 & 7.2 \\
$\mathrm{Cond}(\mathrm{mS} / \mathrm{cm})$ & 61.9 & 63.5 & 62.4 & 61 & 62.7 & 61.4 \\
$\mathrm{~T}^{\circ} \mathrm{C}$ & 19 & 19 & 19 & 19 & 19 & 19 \\
\hline
\end{tabular}

On the basis of a substantial reduction in iron following treatment, it was considered that the risk of iron precipitation and scaling or blockage of the system using treated water would be very low. Furthermore, the temperature of the mine water was not appreciably reduced during the treatment process. As such, the treated water was selected for use in the first trial system. The following sections document a comparison between the applications of treated and untreated mine water in a heat pump system. 


\subsection{Heat pump system setup}

A $12 \mathrm{~kW}_{\text {th }}$ Danfoss ${ }^{\mathrm{TM}}$ DHP-H OPTI PRO unit was installed at Dawdon. ( $\mathrm{KW}_{\text {th }}$ refers to the thermal output power of the heat pump, which is a product of electrical input power and thermal source power as defined by the coefficient of performance ratio.) This is connected to 18 domestic-type radiators providing heating for the offices, workshops and crew rooms of the plant, in addition to hot water draw off points, connected to a $210 \mathrm{~L}$ buffer tank and immersion heater. By providing a large surface area of radiators (approximately $60 \mathrm{~m}^{2}$ ), the temperature requirements for heating are less than for a smaller area of radiators. It was intended that the resultant increased efficiency would mimic underfloor heating systems, which would be typical of ground-source heat installations. The heat pump unit itself is located within the chemical store room (Figure 2), offering some protection from the operation of the treatment facility, in particular from salt deposition from the air, which occurs in the main building.

A glycol solution is circulated in an external (secondary) loop from the heat pump unit, the intention of which is to isolate the refrigerant gas circuit from the environment in normal application (e.g., shallow ground-sourced closed-loop systems or groundwater-sourced closed-loop systems, as described by Banks, 2008,2009 ). In these applications, a significant risk of refrigerant (typically consisting of organofluorine compounds) leakage exists from large lengths of unprotected pipe, raising concerns of pollution, even if the practical consequences are minimal (Banks, 2008, p. 126). At Dawdon, an additional (tertiary) pumped loop circulates mine water through a tube in shell-type heat exchanger (Figure 2 inset), coupled to the secondary glycol solution circuit (see Figure 3 for schematic diagram). While this introduces small inefficiencies within the system, it provides a flexible and practical means of coupling the heat pump to mine water.

To allow detailed interrogation of the system performance, a network of monitoring equipment was installed to measure temperature and power. These monitors are coupled to a telemetry system that collects the data. Data for system performance are not presented in this paper.
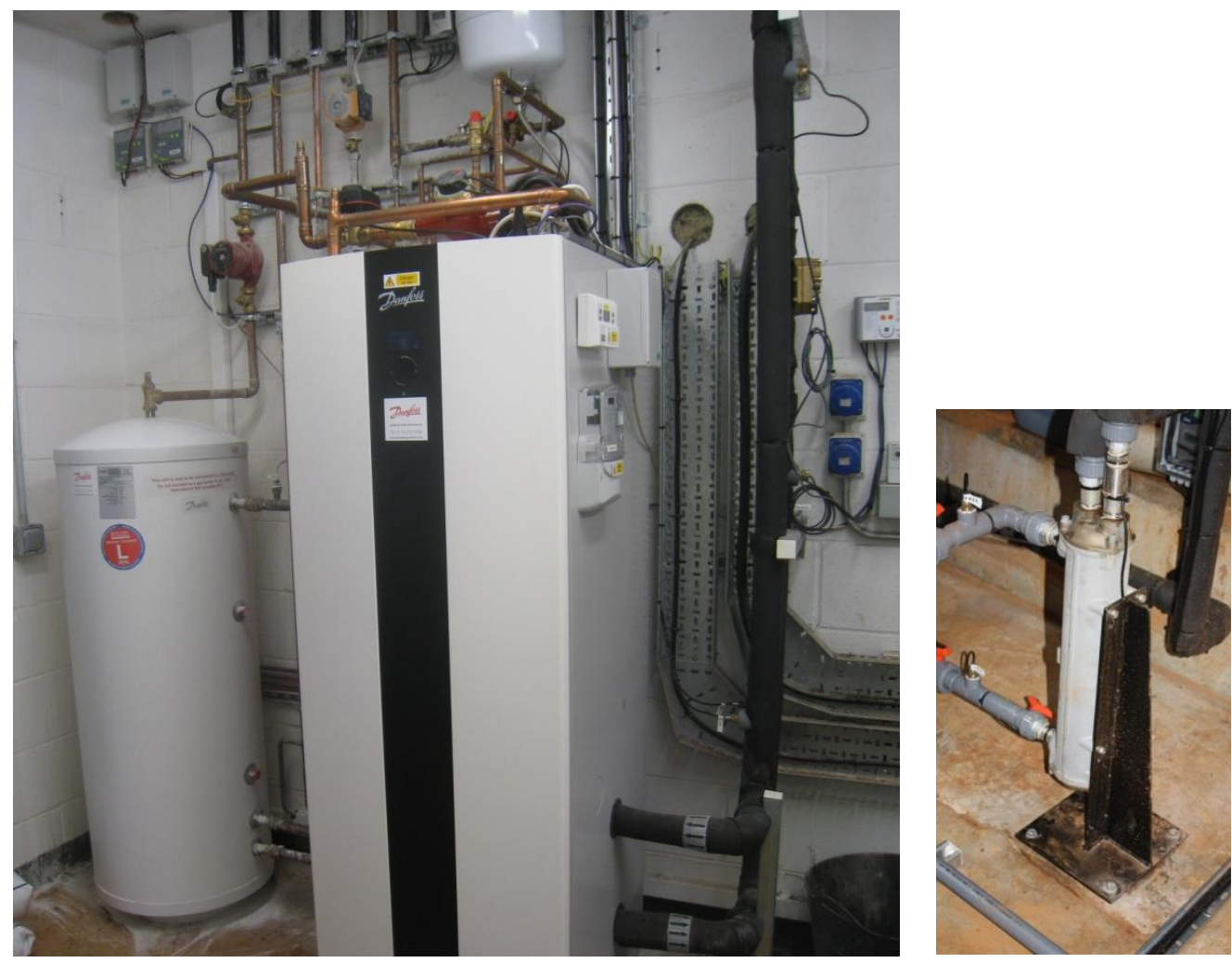

Figure 2 Heat pump (centre) and buffer tank (left) within chemical store room; inset shows tube in shell heat exchanger, which is coupled to the mine water feed 


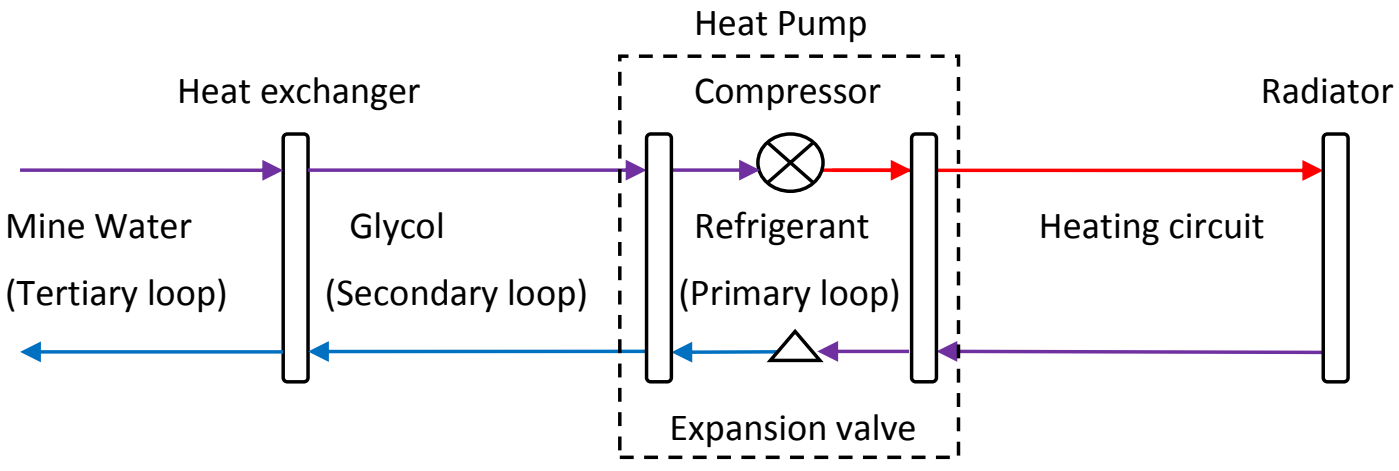

Figure 3 Schematic diagram of heat pump system installed at Dawdon

\subsection{Application of treated mine water for heat extraction}

Commissioning of the heat pump system took place in April 2011, and approximately $1 \mathrm{~L} / \mathrm{s}$ of treated mine water was initially passed through a tube and shell type heat exchanger before being returned to the discharge tank. The tube in shell heat exchangers consists of a series of narrow tubes, in this instance carrying mine water, contained within a larger shell through which glycol circulates. The high surface area presented to the glycol by the narrow tubes allows heat to be rapidly transferred to it from the warmer mine water. After several months of operation, in June 2011 visual reports of a progressively decreasing flow rate and poor efficiency suggested that the mine-water loop was becoming blocked. An investigation into this suspected blockage found the heat exchanger tubes to be heavily clogged with what appeared to be ochre (iron hydroxide) particles, despite the mine water having received treatment to reduce iron prior to circulation. Figure 4 shows ochre accretion on the inlet pipe work, which feeds mine water into the heat exchanger tubes.

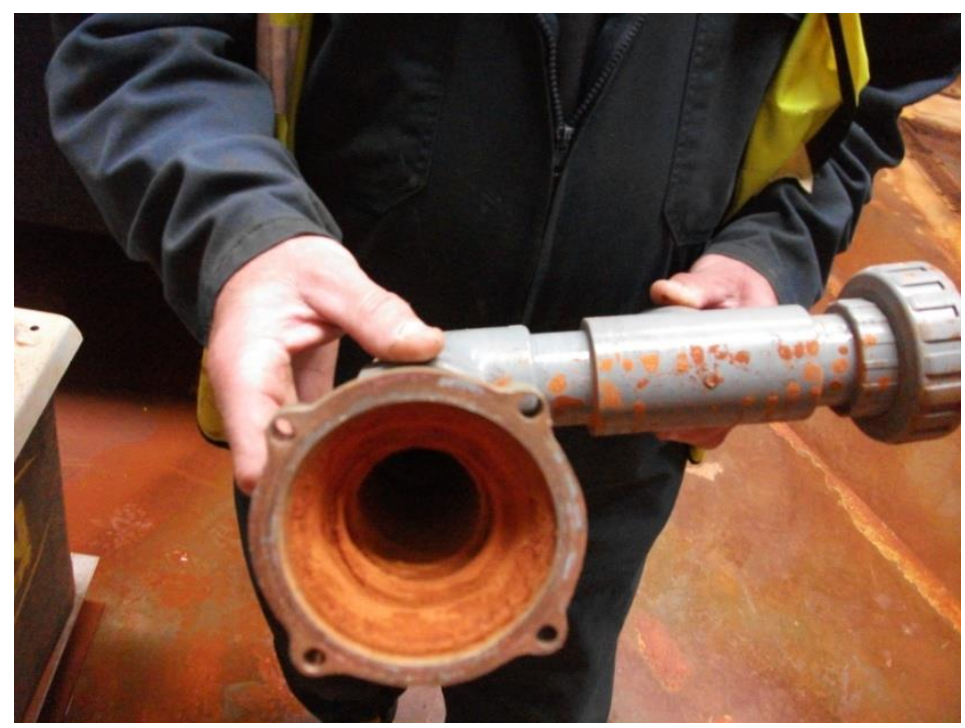

Figure 4 Amorphous iron hydroxide precipitates within inlet of heat exchanger

Recommissioning of the system was undertaken over the summer of 2011, at which time heating demand was low, with a replacement heat exchanger along with a particle filter and flow meter being installed. It was hoped that any ochre particles would be removed by the filter (dissolved iron should be completely removed by the treatment process) and any changes in flow could be accurately gauged. Restarting of the system was delayed until October 2011 due to unseasonably warm weather. Upon restarting, the system operated intermittently due to low heating demand. Figure 5 shows the mine-water flow rate, which was consequently intermittent within the first couple of months. Effective space heating was achieved throughout the operational period, but progressive decrease of mine-water flow through the heat 
exchanger, as shown in Figure 5, eventually triggered system shut down in January 2012 after approximately four months of operation.

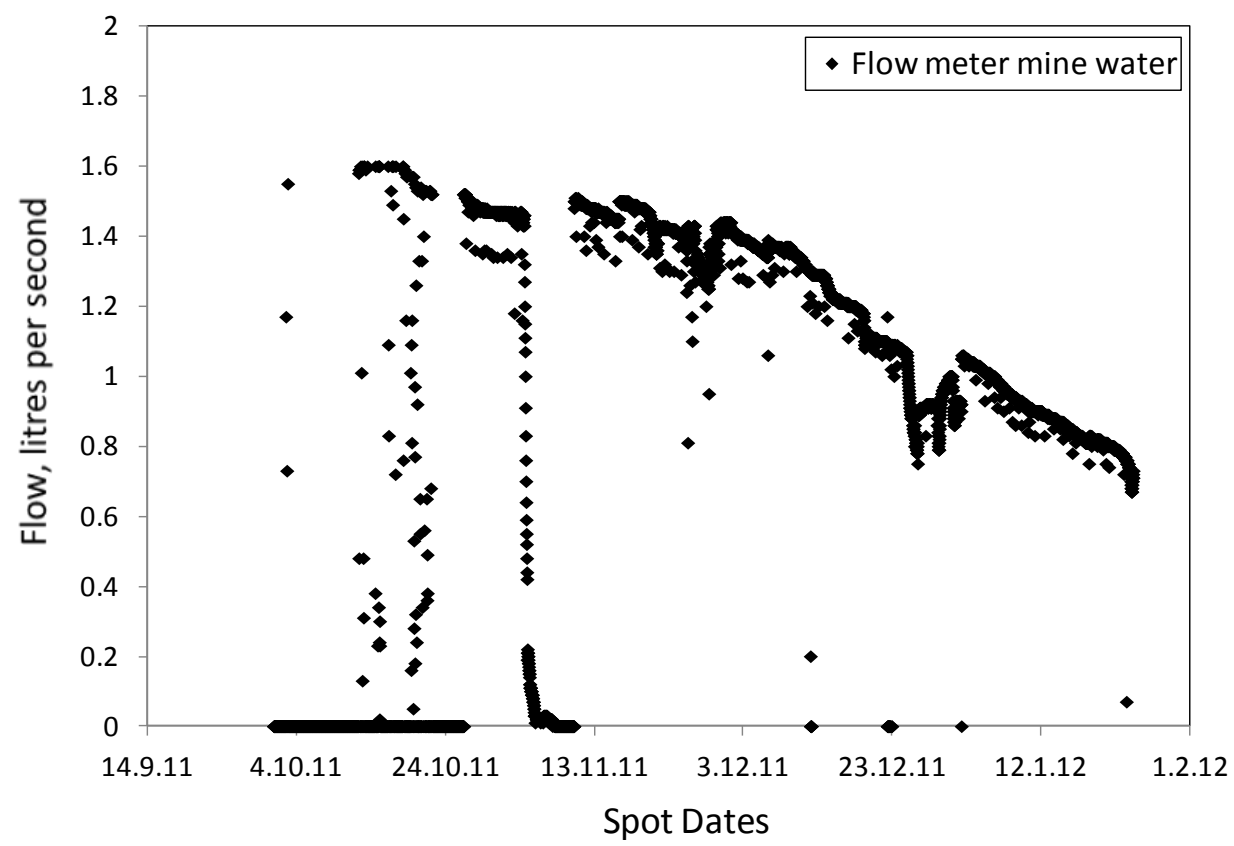

Figure 5 Flow measurement in treated mine-water circuit

\section{$3 \quad$ Precipitate analysis and geochemical modelling}

In order to confirm the materials causing blockage of the heat exchanger within the treated mine-water circuit, mineralogical analysis of the precipitate and geochemical speciation modelling of the mine water were undertaken.

\subsection{X-Ray diffraction (XRD) analysis}

Precipitate material, which was orange and powdery in consistency, was collected from the inside tubes of the tube-in shell heat exchanger, and submitted for XRD analysis. The following results were obtained:

- Major phases - amorphous 67.9\%; calcite $20.5 \%$; halite $9.5 \%$.

- Minor phases - goethite $2 \%$; magnetite $0.1 \%$.

Discussion with the laboratory revealed that the amorphous phases (which cannot be identified by XRD) were believed to be amorphous iron hydroxides. A significant calcite component was also identified (20.5\%) alongside halite $(9.5 \%)$ and a range of iron oxide/hydroxide minerals.

\subsection{PHREEQC geochemical speciation modelling}

Geochemical speciation analysis was undertaken of two representative theoretical solutions of treated mine water, using the PHREEQC software (Parkhurst and Appelo, 2011). Solution 1 is characterised by typical water chemistry during optimum plant performance (iron concentration $0.7 \mathrm{mg} / \mathrm{l}$ ); solution 2 indicates quality during sub-optimal plant performance (iron concentration of $2 \mathrm{mg} / \mathrm{l}$ ) - see Table 3 .

PHREEQC results, presented in Table 4, indicate that $\mathrm{Fe}(\mathrm{OH})_{3}$, goethite, haematite and jarosite (ironcontaining minerals) are all supersaturated. Other supersaturated species are alunite and gibbsite (aluminium containing minerals), rhodochrosite (managanese carbonate) in both solutions and dolomite in solution 2, perhaps not unexpectedly, considering elevated aluminium and magnesium concentrations (respectively) commonly characteristic of coal mine waters. Calcite and aragonite are also slightly supersaturated in solution 2 , since the saturation index (SI) of 0.8 is greater than 0 , therefore only minor 
changes in conditions (e.g., temperature) could cause precipitation, based upon the samples analysed. (SI provides an indication as to whether a compound (e.g., a salt) is either undersaturated or oversaturated in a solution. A value $<0$ indicates the salt is undersaturated (i.e., a salt will dissolve); a value $>0$ indicates the solution is oversaturated with the salt, which will therefore precipitate.) Halite is undersaturated (anticipated due to the high solubility of chloride) in the geochemical modelling, and it is suspected that the halite identified during the XRD analysis resulted from evaporation of saline water from the heat exchanger when it was uncoupled from the system. Highly supersaturated iron minerals were identified, as expected, corroborating with the XRD analysis. Thus it can be reasonably concluded that iron oxide/hydroxide formation was the principal cause of the blockages of the heat exchanger in the treated water circuit.

Table 3 Treated mine-water parameters used for geochemical modelling

\begin{tabular}{ccc}
\hline & Solution 1 & Solution 2 \\
\hline Temperature $\left({ }^{\circ} \mathrm{C}\right)$ & 19 & 19 \\
Eh $^{1}$ & 7.4 & 7.4 \\
Density & 4 & 4 \\
Alkalinity $\left(\mathrm{mg} / \mathrm{L}\right.$ as CaCO $\left.{ }^{3}\right)$ & 1.025 & 1.025 \\
Calcium $(\mathrm{mg} / \mathrm{L})$ & 402 & 401 \\
Chlorine $(\mathrm{mg} / \mathrm{L})$ & 1,048 & 10.55 \\
Potassium $(\mathrm{mg} / \mathrm{L})$ & 19,366 & 19,362 \\
Magnesium (mg/L) & 904 & 916 \\
Sodium (mg/L) & 686 & 691 \\
Sulphur (mg/l) & 15,706 & 15,771 \\
Iron (mg/L) & 2,987 & 3,008 \\
Manganese (mg/L) & 0.7 & 2 \\
Aluminium (mg/L) & 2.1 & 2.2 \\
Nitrogen (mg/L) & 0.4 & 0.4 \\
\hline
\end{tabular}

\footnotetext{
${ }^{1}$ Eh assumed for aerated water.
}

2 Density calculated. 


\begin{tabular}{|c|c|c|}
\hline Mineral & SI Solution 1 & SI Solution 2 \\
\hline $\mathrm{Al}(\mathrm{OH})_{3}$ & -0.24 & -0.24 \\
\hline Alunite $\mathrm{KAl}_{3}\left(\mathrm{SO}_{4}\right)_{2}(\mathrm{OH})_{6}$ & 4.51 & 4.42 \\
\hline Anhydrite $\mathrm{CaSO}_{4}$ & -2.39 & -0.43 \\
\hline Aragonite $\mathrm{CaCO}_{3}$ & -1.28 & 0.69 \\
\hline Calcite $\mathrm{CaCO}_{3}$ & -1.13 & 0.84 \\
\hline $\mathrm{CO}_{2}(\mathrm{~g})$ & -1.97 & -2 \\
\hline Dolomite $\mathrm{CaMg}\left(\mathrm{CO}_{3}\right)_{2}$ & -0.13 & 1.83 \\
\hline $\mathrm{Fe}(\mathrm{OH})_{3}$ & 2.78 & 2.33 \\
\hline Gibbsite $\mathrm{Al}(\mathrm{OH})_{3}$ & 2.5 & 2.51 \\
\hline Goethite FeOOH & 8.47 & 8.01 \\
\hline Gypsum CaSO${ }_{4}: 2 \mathrm{H}_{2} \mathrm{O}$ & -2.17 & -0.21 \\
\hline Halite $\mathrm{NaCl}$ & -2.34 & -2.35 \\
\hline Hausmannite $\mathrm{Mn}_{3} \mathrm{O}_{4}$ & -11.22 & -11.27 \\
\hline Hematite $\mathrm{Fe}_{2} \mathrm{O}_{3}$ & 18.92 & 18.01 \\
\hline Jarosite- $\mathrm{K} \mathrm{KFe}_{3}\left(\mathrm{SO}_{4}\right)_{2}(\mathrm{OH})_{6}$ & 2.75 & 1.3 \\
\hline Manganite $\mathrm{MnOOH}$ & -4.44 & -4.45 \\
\hline Melanterite $\mathrm{FeSO}_{4}: 7 \mathrm{H}_{2} \mathrm{O}$ & -5.62 & -6.11 \\
\hline Pyrochroite $\mathrm{Mn}(\mathrm{OH})_{2}$ & -5.7 & -5.71 \\
\hline Pyrolusite $\mathrm{MnO}_{2}$ & -10.06 & -10.07 \\
\hline Rhodochrosite $\mathrm{MnCO}_{3}$ & 0.48 & 0.44 \\
\hline Siderite $\mathrm{FeCO}_{3}$ & 0.17 & -0.31 \\
\hline
\end{tabular}

\section{$4 \quad$ Use of untreated mine water}

Despite the presence of many open mine shafts offering access to the vast quantities of 'warm' mine water, there has been a certain reluctance to exploit this resource for heating or cooling applications more widely within the UK. Perhaps the greatest conceivable reason for this, particularly among industry specialists, is that the ferruginous nature of many mine waters is renowned for accreting and causing blockages within pipe work of treatment systems. This indeed led to the initial commissioning of the Dawdon heat pump system using a treated mine-water feed, in an attempt to avoid these issues.

Experience at the Shettleston and Lumphinnans sites using poor-quality untreated mine water found no significant accumulations of iron or other precipitates within the pipe work or heat exchangers. Hydrochemical modelling simulated by Banks et al. (2009) suggests that this success is achieved by maintaining a pressurised system that excludes oxygen, thus maintaining solubility of dissolved species such as iron. Although raw mine water at the Dawdon treatment site is considerably worse in quality than at Shettleston and Lumphinnans, the principle of maintaining dissolved species within a pressurised system should still apply. If gaseous oxygen is introduced to the system, it readily dissolves and species such as iron are oxidised (1) and hydrolysed (2) to less soluble species such as hydroxides/oxy-hydroxides; an example of this is provided in the following equation (after Banks et al., 1997): 


$$
\begin{gathered}
4 \mathrm{Fe}_{2+(a q)}+\mathrm{O}_{2(a q)}+4 \mathrm{H}^{+{ }_{(a q)}}=4 \mathrm{Fe}^{3+{ }_{(a q)} 2 \mathrm{H}_{2} \mathrm{O}_{(l)}} \\
\mathrm{Fe}^{3+(a q)}+3 \mathrm{H}_{2} \mathrm{O}_{(l)}=\mathrm{FeOOH}_{(s)}+\mathrm{H}_{2} \mathrm{O}_{(l)}+3 \mathrm{H}^{+}(a q)=\mathrm{Fe}(\mathrm{OH})_{3(s)}+3 \mathrm{H}^{+}(a q)
\end{gathered}
$$

On this basis, the Dawdon system was re-configured using a raw mine-water feed, in an attempt to exclude atmospheric oxygen.

\subsection{Reconfiguration of Dawdon heat pump with raw mine-water feed}

Reconfiguration of the system was undertaken during August and September 2012, coupling a heat exchanger to a raw mine-water feed taken from the plant inlet main. Water was delivered to the heat exchanger in a pressurised rising main, which was coupled to a submersible pump in the mine shaft. The heat exchanger was a like-for-like replacement to that used in the treated mine water circuit, and was coupled to the same glycol feed. Once the mine water had passed through the heat exchanger, it was returned to the mine-water treatment mixer tanks approximately $8 \mathrm{~m}$ above the inlet. Commissioning of the system took place in October 2012, after which the heat pump operated intermittently, dependent upon heating demand from the thermostat in the office complex. Flow rates of the mine water were determined by the pressure of the plant delivery main (there was no auxiliary pump) and remained at $1 \mathrm{~L} / \mathrm{s} \pm 0.2 \mathrm{~L} / \mathrm{s}$ for the trial period - similar to the treated mine water configuration.

As of April 2013, the system has been operating effectively, and data on performance are being collected. No reports of clogging of the heat exchanger have been made to date, and inspection of the strainer indicates that no iron accumulation has occurred. Findings to date indicate that poor-quality ferruginous and hypersaline mine water can be a suitable heat source for mine-water-sourced heating schemes that use 'off the shelf' heat exchangers. The same water, after treatment, has a demonstrable impact upon the performance of heat exchangers, leading to rapid failure of the pilot system. If untreated mine water proves a successful source over a long time period, further confidence will be gained in the application of this system at abandoned mine sites, whether there is a mine-water treatment system or not. Further monitoring of the system is to be undertaken, in order to assess if any deterioration of heat exchanger performance occurs over time.

\section{Conclusions}

This paper reports on the testing of a hypersaline and ferruginous raw (untreated) and treated (i.e., for the removal of iron) mine water through heat exchangers in a pilot scale mine-water-sourced heating scheme. Data indicate that water immediately after treatment is supersaturated with various mineral phases, which rapidly precipitate and cause blockage of heat exchangers over a period of less than three months. This is considered to be a result of oxidation of species such as iron, which convert from aqueous phase ferrous ions to solid phase ferric oxide/hydroxides. In contrast, over a six-month period the raw mine water has not clogged the same heat exchangers, due to the absence of oxygen within the sealed and pressurised system. It has therefore been demonstrated over a short period that hypersaline and ferruginous mine do not cause blockage problems with commercially available 'off the shelf' heat exchangers, provided that they remain anoxic by exclusion of atmospheric oxygen. Ongoing monitoring is required to demonstrate the longevity of this setup however.

Heat pump technology can be applied to poor-quality mine waters at closed mine sites to provide 'green' heating to new or existing buildings. Site conditions must be considered during closure to facilitate economic development of these schemes, which may be a catalyst for redevelopment. This may include leaving mine surface infrastructure in-situ but also, more importantly, ensuring that mine shafts are not backfilled until their suitability for use as a sustainable heat resource has been considered. 


\section{Acknowledgement}

Martyn Tittley of IWS Ltd is acknowledged for his expertise and enthusiasm in setting up the heat pump system. Acknowledgements are also extended to the plant managers John Hankey and Tony Keeney, who acted as guinea pigs for this trial.

\section{References}

Banks, D. (2008) An Introduction to Thermogeology: Ground Sourced Heating and Cooling, Blackwell.

Banks, D. (2009) An introduction to 'thermogeology' and the exploitation of ground source heat, Quarterly Journal of Engineering Geology and Hydrogeology, Vol. 42(3), pp. 283-293.

Banks, D., Younger, P.L., Arnesen, R.T., Iversen, E.R. and Banks, S.B. (1997) Mine-water chemistry: the good, the bad and the ugly, Environmental Geology, Vol. 32(3), pp. 157-174.

Banks, D., Skarphagen, H., Wiltshire, R. and Jessop, C. (2003) Mine water as a resource: space heating and cooling via use of heat pumps, Land Contamination \& Reclamation, Vol. 11(2), pp. 191-198.

Banks, D., Fraga Pumar, A. and Watson, I. (2009) The operational performance of Scottish minewater-based ground source heat pump systems, Quarterly Journal of Engineering Geology and Hydrogeology, Vol. 42(3), pp. 347-357.

Hall, A., Scott, J.A. and Shang, H. (2011) Geothermal energy recovery from underground mines, Renewable and Sustainable Energy Reviews, Vol. 15(2), pp. 916-924.

Jessop, A.M., Macdonald, J.K. and Spence, H. (1995) Clean energy from abandoned mines at Springhill, Nova Scotia, Energy Sources, Vol. 17(1), pp. 93-106.

Parker, K. (2003) Mine water management on a national scale - experiences from the Coal Authority, Land Contamination \& Reclamation, Vol. 11(2), pp. 181-190.

Parkhurst, D.L. and Appelo, C.A.J. (2011) Description of input and examples for PHREEQC version 3-A computer program for speciation, batch-reaction, one-dimensional transport, and inverse geochemical calculations: U.S. Geological Survey Techniques and Methods, Book 6, Chap. A43, 497 p., available only at http://pubs.usgs.gov/tm/06/a43.

Roijen, E.I.E. (2011) The use of an open-loop heat-pump system to heat social housing and an office building throughout the town of Heerlen, the Netherlands, in Heat Pump Technology Using Minewater, M.L. Faull (ed).

Watzlaf, G.R. and Ackman, T.E. (2006) Underground mine water for heating and cooling using geothermal heat pump systems, Mine Water and the Environment, Vol. 25, pp. 1-14.

Watzlaf, G.R., Kairies, C.L., Schroeder, K.T., Danehy, T. and Beam, R. (2002) Quantitative results from the flushing of four reducing and alkalinity producing systems, in Proceedings The West Virginia Surface Mine Drainage Task Force Symposium.

Wieber, G. and Pohl, S. (2008) Mine water: a source of geothermal energy - examples from the Rhenish Massif, in Proceedings International Mine Water Association Congress, 2-5 June 2008, Karlsbad, Czech Republic.

Wyatt, L.M., Moorhouse, A.M.L., Kershaw, S. and Iwanskyj, B. (2013) Mine water: management post closure and lessons learned; risks from poor closure management and mine water management, in Proceedings Eighth International Conference on Mine Closure 2013 (Mine Closure 2013), M. Tibbett, A.B. Fourie and C. Digby (eds), 18-20 September 2013, Cornwall, UK. 